\title{
Alternatives to Expedite Macroeconomic Convergence of the SADC Countries
}

\author{
Jannie Rossouw ${ }^{1}$ and Johan Fourie ${ }^{2}$
}

Countries comprising the Southern African Development Community (SADC) region show satisfactory progress with the achievement of the region's macroeconomic convergence goals. Five countries achieved all four goals set for 2008 already by 2006: five achieved three of the goals and the other four achieved two goals. In addition, countries in the SADC region have achieved their target for the establishment of a free trade area. The achievement of these goals supports SADC's ultimate objective of establishing a regional central bank with a single regional currency by 2016.

Since 1857, European experiences with monetary unions have shown that unification can at best be regarded as a challenging prospect for any region. Judged in terms of the European experience, SADC does not face insurmountable challenges in its quest for monetary unification and a single central bank. However, governments of countries in the SADC region should consider whether a regional central bank should follow discretionary monetary policy catering for particular economic shocks, or monetary policy based on rules using a monetary policy anchor. Neither approach leaves easy choices, as governments of SADC countries would have to establish a structure to consider and select a monetary policy anchor.

At a microeconomic level, the benefits of establishing a regional central bank and adopting a single regional currency are to free private enterprises, business firms and individuals from transaction costs in intraregional trade and travel. It will also increase price transparency and competition between countries and stabilize consumer prices in countries suffering prolonged inflation due to sustained exchange rate depreciation.

Four initiatives can enhance SADC's progress. First, the macroeconomic convergence criteria should be clarified and the timely publication of macroeconomic data should be ensured. Secondly, the measurement of inflation should be harmonized between countries and the credibility of inflation figures should be assessed to ensure that the consequences of the introduction of a single currency is not associated with monetary policy causing only pain and no tangible benefits. Thirdly, the legal, regulatory and supervisory framework of 
financial institutions within SADC should be harmonised. Lastly, SADC countries should consider a suitable monetary framework for a regional central bank.

Research on the achievement of the goals of countries in the SADC region should be regarded as work-in-progress. It is still too early to reach final conclusions on initiatives aimed at goals to be achieved only in 2016 .

JEL Classifications: E 31, E42, E58, F15

Key words: financial institutions; household savings macro-economic convergence; regulation and supervision of financial institutions; monetary policy choices; SADC

Corresponding author: jannie.rossouw@resbank.co.za

\footnotetext{
1 SA Reserve Bank and Economics Department, University of Pretoria.

2 SA Reserve Bank.

This overview reflects the personal views of the authors.
} 


\section{Selected references}

1 BACKGROUND INFORMATION ON SADC (2000) [Online].http://www.sadcsqam.org/ [Accessed on 12 April 2005].

2 BARRO, R. and GORDON, D. (1983) Rules, discretion and reputation in a model of monetary policy. Journal of Monetary Economics. Vol 12: 1. January.

3 COMMITTEE OF CENTRAL BANK GOVERNORS (2007) Recent economic developments and statistics for SADC countries. Secretariat of the Committee of Central Bank Governors. Pretoria: SA Reserve Bank.

4 ECB CONVERGENCE REPORT (2006) May. [Online]. www.ecb.int/pub/pdf/conrep/cr2006en.pdf [Accessed on 24 January 2007].

5 KYDLAND, F. E. and PRESCOTT, E. C. (1977) Rules rather than discretion: The time inconsistency of optimal plans. Journal of Political Economy. Vol 85: 3. June.

6 MASSON, P. R. and PATTILLO, C. (2005) The monetary geography of Africa. Washington: Brookings Institution Press.

7 MBOWENI, T. T. (2003) African Economic Integration - Keynote address at the 5th Annual African Development Finance Conference. 9 October. [Online]. http://www.resbank.co.za [Accessed on 27 March 2006].

8 (2005) Media briefing on SADC by the Chairperson of the Committee of Central Bank Governors in Cape Town, after a meeting of the CCBG of SADC and the European Central Bank. 28 February. Internal document of the SA Reserve Bank.

9 ROSSOUW, J. (2008) Inflation in South Africa: 1921 to 2006. History, measurement and credibility. Unpublished PhD-thesis. University of KwaZuluNatal: Durban.

10 ROSSOUW, J. en FOURIE, J. (2007) Is groeiende welvaart teenoor armoede ' $n$ nul-som spel? Tydskrif vir Geesteswetenskappe. Ter perse.

11 SA RESERVE BANK (2007) Integrated Paper on Recent Economic Developments in SADC. Internal document of the SA Reserve Bank.

12 SOUTHERN AFRICAN DEVELOPMENT COMMUNITY (2002) Memorandum of Understanding concluded between Southern African Development Community member states on macroeconomic convergence. August. 
13 SOUTHERN AFRICAN DEVELOPMENT COMMUNITY ([S.a.]) Regional Indicative Strategic Development Plan (RISDP). [Online]. http://www.sadc.int/english/documents/risdp/index.php [Accessed on 1 November 2006].

14 VANTHOOR, W.F.V. (1996) European Monetary Union since 1848: a political and historical analysis. Cheltenham: Edward Elgar Publishing Limited. 